\title{
Pollen Preference of Honeybees Depending on Protein Contents
}

\author{
Şeref Cınbırtoğlu ${ }^{1, *}\left(\mathbb{D}\right.$, Fazıl Güney ${ }^{1}$ \\ ${ }^{1}$ Apiculture Research Institute Directorate, Ordu, Turkey
}

\section{Article History}

Received 12 April 2021

Accepted 01 June 2021

First Online 07 June 2021

\section{*Corresponding Author}

Tel.: +905383003110

E-mail: seref.cinbirtoglu@tarimorman.gov.tr

\section{Keywords}

Honey bee (Apis mellifera L.)

Lamium purpureum $\mathrm{L}$.

Pollen choice

Protein

Trifolium repens $\mathrm{L}$.

\begin{abstract}
This study was carried out in the spring period of 2013 and 2015 in Turkey. Pollen traps were attached to the colonies when the flight activity starts, in the flowering period of March, April, and May. The reference pollen slides were prepared, and pollens collected by bees were determined using reference pollen slides by microscopic examination. The protein contents of the bee pollens were also evaluated. Protein contents of pollens varied between $7.27 \%-24.90 \%$ in 2013 and $7.47 \%-21.82 \%$ in 2015 . The highest protein content was determined in Lamium purpureum L., while the lowest protein was found in Carex $s p$. Honeybees preferred mostly the pollens of Laurocerasus officinalis R., Ornithogalum sp. and Taraxacum officinale W. in March, Juglans regia L., and Bellis perennis L. in April, Diospyros lotus L., and Trifolium repens $\mathrm{L}$. in May.
\end{abstract}

\section{Introduction}

The pollen is the primary natural protein sources of honeybees. It is crucial for honeybees, and they need pollen mostly in spring and the beginning of the summer for breeding, beeswax producing, brooding, and population increasing activities (Guler, 2017).

Pollen gathering and storage at adequate levels are crucial for entering the main nectar flow with healthy worker bees, maintaining broods' reproduction, and consequently providing desired honey production (Erdogan \& Dodologlu, 2005). A bee colony can collect about $18-50 \mathrm{~kg}$ of pollen per year, and a honeybee consumes 120-145 mg pollen from the egg stage to adulthood (Sammataro \& Avitabile, 1998).

200 substances are identified in pollen, including proteins, amino acids, carbohydrates, lipids and fatty acids, phenolic compounds, enzymes, vitamins and bio elements at different proportions according to the floral source (Komosinska-Vassev, Olczyk, Kaźmierczak, Mencner, \& Olczyk, 2015). It is not precisely explained whether honeybees choose pollen according to the quality, odour, or other visual properties (Lunau, 2000).

Every flora and geographic region has some specific or endemic plants as a nectar source. Beekeeping is not possible without flowers. For that reason, beekeepers have to move their hives to fields, which have a long flowering period and pollen source plants (Öztürk, Yalçın, \& Tutkun, 2001). It is necessary to discover the species of pollen plants that honeybees visit extensively (Tutkun, 2011). In the studies related to this topic, plants in different floras preferred by honeybees (Apis mellifera L.) as pollen sources, were detected.

The plants preferred by honeybees for pollen source are not well known in the study field. Thus, this 
study aimed to identify essential plants that honeybees use as pollen sources and measuring their protein contents.

\section{Materials and Methods}

This research was carried out in the area of 20000 decares in Dedeli Village, which represents the flora of Ordu City. Plant species, pollen grains and protein content were determined in March, April and May of 2013-2015. No data was collected due to unfavourable seasonal and floral conditions in 2014. Pollen samples were collected with traps placed in beehives. Pollen traps were set between 07:00-15:00 o'clock on days when flowers bloom and seasonal conditions are favourable for bees to forage. According to Sawyer (1988) method, 200 pollen pellets were randomly collected from 3 colonies separately and daily. The fresh pollen pellets collected from the hives were classified according to their colours and then microscopically examined.

\section{Preparation of Reference Pollen Slides}

The collected plants were identified with the aid of literature and then labelled. (Anonymous, 2008; Anonymous, 2013; Davis, 1965-1985; Gungor, Atatoprak, Ozer, Akdag, \& Kandemir, 2007). Firstly, reference pollen slides were prepared according to Louveaux, Maurizio and Vorwohl (1978). Briefly, pollen taken from anthers was placed on a clean slide and 2-3 drops of $96 \%$ alcohol were dripped on it. The slides were kept on the heater until the alcohol evaporated, then basic fuchsine was added. Some glycerin-gelatin was put on the pollens and melted. It was mixed with a clean needle to distribute the pollen, and a coverslip was covered on it. Slides were left to dry by turning them upside down and sealed with paraffin. These slides were used for later comparison with the pollen types.

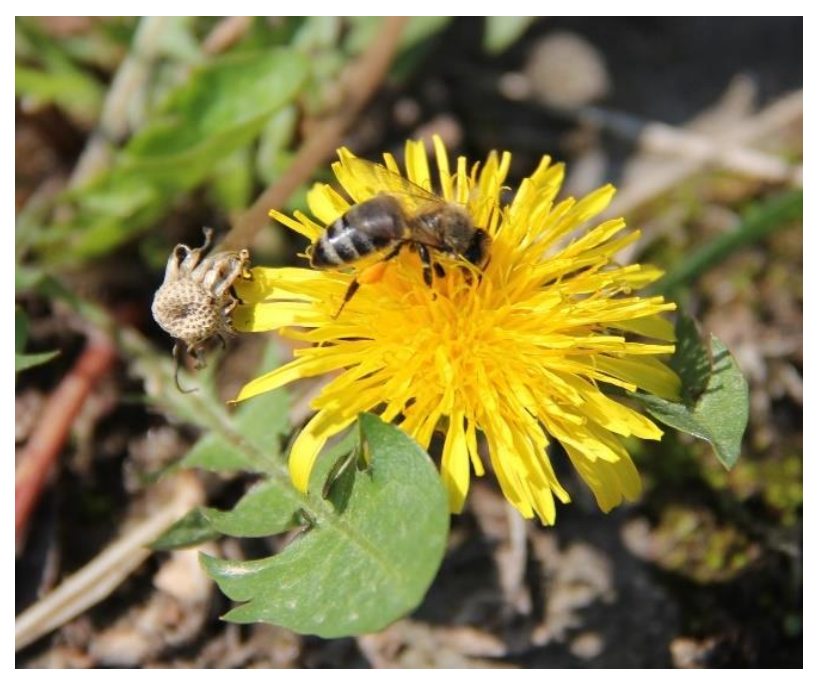

Figure 1. Taraxacum officinale W. plant collected for reference pollen slides

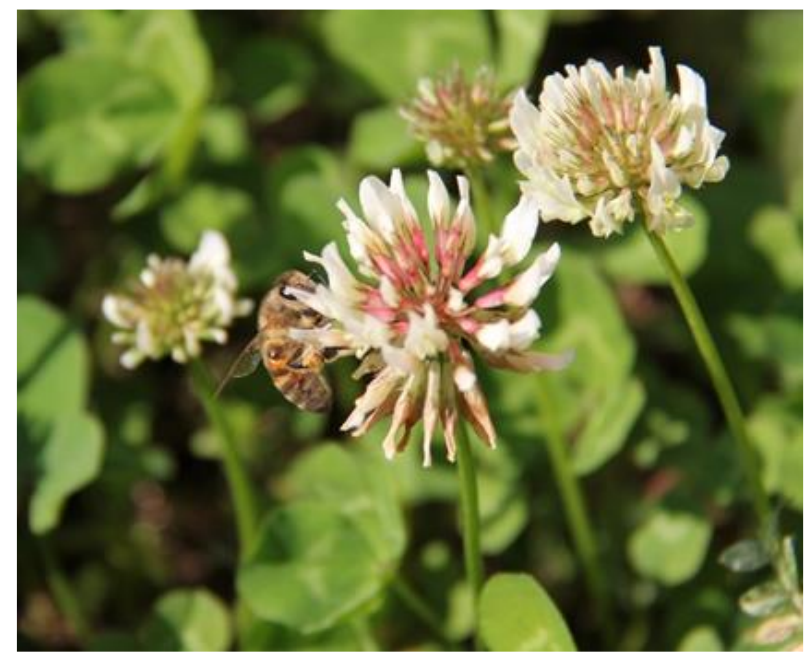

Figure 2. Trifolium repens L. plant collected for reference pollen slides

\section{Identification of pollens}

Pollen grains were prepared and identified according to Louveaux et al. (1978). The pollen slides were researched with Zeiss Axio Scope A1 microscope and identified with the aid of prepared reference pollen slides and with the use of microphotographs from the literature (Sorkun, 2008; PalDat, 2015).
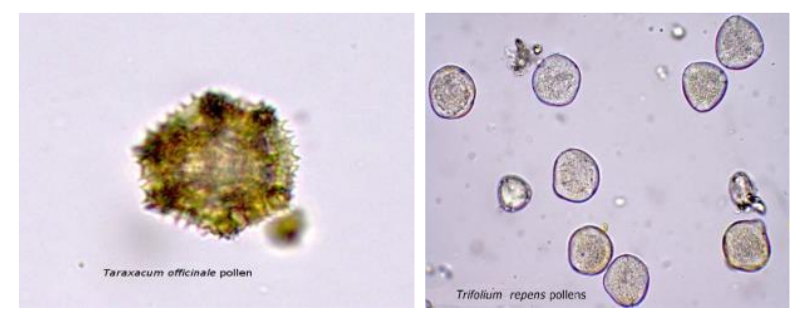

Figure 3. Some view of identified pollens in a microscope

\section{Protein Analyses of Pollens}

The protein analyses were performed with a protein-nitrogen analyzer (LECO FP-528, USA). According to Dumas principle, samples were heated to destruction in a combustion tube at high temperatures $\left(900-1200^{\circ} \mathrm{C}\right)$ in an oxygen atmosphere (AOAC, 2002).

\section{Results}

Protein contents of pollens preferred by honeybees are given in Table 1. Protein amount, a crucial quality property of pollens, showed a significant variation in plant species. It was found that Lamium purpureum L. pollens have the most considerable protein amount and Carex sp. pollens contain the least amount of protein. On the other hand, Trifolium repens L., Laurocerasus officinalis R. and Diospyros lotus L. pollens also had more protein than the rest of the plants. 
Table 1. Protein contents of pollens collected by honeybees in 2013 and 2015

\begin{tabular}{lcc}
\hline \multirow{2}{*}{ Species } & \multicolumn{2}{c}{ Protein (\%) (Av. \pm SD) } \\
\cline { 2 - 3 } & 2013 & 2015 \\
\hline Lamium purpureum L. & $24.90 \pm 2.02$ & $21.82 \pm 0.39$ \\
Diospyros lotus L. & $23.13 \pm 0.98$ & $20.99 \pm 0.10$ \\
Laurocerasus officinalis R. & $22.85 \pm 0.60$ & $18.91 \pm 1.39$ \\
Trifolium repens L. & $22.39 \pm 1.46$ & $19.31 \pm 0.54$ \\
Ornithogalum sp. & $17.26 \pm 1.61$ & $18.84 \pm 0.40$ \\
Taraxacum officinale W. & $16.23 \pm 3.52$ & $15.91 \pm 1.83$ \\
Salix sp. & $15.92 \pm 1.04$ & $16.85 \pm 0.34$ \\
Veronica sp. & $14.57 \pm 0.34$ & $14.09 \pm 0.67$ \\
Bellis perennis L. & $13.65 \pm 0.59$ & $12.19 \pm 0.27$ \\
Geranium asphodeloides B. & $13.45 \pm 0.57$ & $13.49 \pm 0.41$ \\
Juglans regia L. & $12.86 \pm 0.68$ & $15.92 \pm 0.26$ \\
Carex sp. & $7.27 \pm 0.65$ & $7.47 \pm 0.48$ \\
\hline Av. \pm SD: Average & & \\
\hline
\end{tabular}

${ }^{*}$ Av. \pm SD: Average \pm Standard Deviation

\section{Discussion}

Protein contents of pollens varied between $7.27 \%$ $-24.90 \%$ in 2013 and $7.47 \%-21.82 \%$ in 2015 . Previous studies support variation of protein amounts, found in our study. It was reported that the protein content of pollen was in a wide range of $2.5 \%-61 \%$ (Roulston, Cane, \& Buchman, 2000). Taha, Al-Kahtani, and Taha (2019) also stated that the protein content of bee pollens may vary between $2.90 \%$ to $33.51 \%$, depending on the botanical origin. In a study conducted in six regions of Turkey, Başdoğan, Sağdıç, Daştan, Düz, and Acar (2019) found the protein values between $16.6 \%$ and $20.2 \%$.

Although protein amounts varied in years, Lamium purpureum L. pollens had the most abundant protein amount while the lowest protein amount was found in Carex sp. Diospyros lotus L., Laurocerasus officinalis R. and Trifolium repens L. pollens were also rich in protein content. The rest of the other plants' protein amount differed between $12.19 \%$ and $18.84 \%$. Teleria, Salgado-Laurenti, Marinozzi, Apóstolo, and Pérez (2019) stated protein amounts of Taraxacum officinale $W$. pollens between $13.25 \%$ and $14.0 \%$. Radev (2018) reported that protein amounts were 24.1\% and $26.0 \%$ for Trifolium repens L. and Lamium purpureum L., respectively. These findings are in accordance with our results.

In our study, it was also observed that honeybees preferred pollens with more protein content.
Laurocerasus officinalis R. was preferred by honey bees as a pollen source in March, while Diospyros lotus L. and Trifolium repens L. were preferred in May. Ghosh, Jeon, and Jung (2020) indicated honey bee colonies collected pollens from Trifolium repens $\mathrm{L}$. first, which had the highest total protein content in their study. Özkök and Sorkun (2016) reported that may be due to the high protein content of poppy pollen, bees preferred the poppy flower at a rate of $84 \%$. Andrada and Telleria (2005) also have stated that honeybees preferred plant species containing high protein levels (Condalia microphylla, Chuquiraga erinacea, Discaria americana, Grindelia tehuelches, Larrea divaricata, Prosopis sp., Prosopidastrum globosum, and Vicia epampicola) in spring. In contrast to our findings; Çelemli, Barkan, Özenirler, Demiralp, and Sorkun (2017) reported that honeybees may not always prefer the pollen types that had higher protein content. These researchers found that the highly preferred pollen had a lower protein content, while the least preferred pollen sample had a relatively higher protein content level.

When the pollen storage was sufficient in the hives in the spring, honeybees primarily preferred protein-rich pollens for their colony activities. However, in the case of protein-rich pollens insufficiency in the flora, honey bees started to collect pollens with lower protein content. It was observed honeybees collected Juglans regia L. pollens and Bellis perennis L. pollens. Even though the protein amounts 
of these pollens were moderate, they were preferred by honey bees extensively.

\section{Conclusion}

The pollen preferences of honey bees may change depending on the flora. The ecological and climatic conditions and also the colony's requirements are responsible for these differences. Honey bees mostly need pollen during breeding and feeding activities, especially in the spring months. It is seen once again in this study, honey bees prefer protein-rich pollens. If the protein-rich pollens are not adequate, honey bees prefer other plants with lower protein content. Within this study's scope, plant species are sufficient and meet the protein requirement for breeding and colony activities in the spring season.

\section{Acknowledgements}

This study is a part of the MSc thesis and supported by Ordu University, with the BAP TF-1302 project number. Analyses were carried out at the Ordu Apiculture Research Institute Directorate. The authors also thank these institutions for supporting with their facilities.

\section{References}

Andrada, A. C., \& Tellería, M. C. (2005). Pollen collected by honey bees (Apis mellifera L.) from south of Caldén district (Argentina): botanical origin and protein content. Grana, 44(2), 115-122.

Anonymous, (2008). Türkiye'nin Çayır ve Mera Bitkileri. Ankara: The Ministry of Agriculture and Rural Affairs, General Directorate of Agricultural Production and Development.

Anonymous, (2013). Turkish Plants Data Service. TÜBiVES. Retrieved from http://turkherb.ibu.edu.tr

AOAC, (2002). AOAC Official method 990.03: Protein (crude) in animal feed. Combustion method.

Başdoğan, G., Sağdıç, O., Daştan, T., Düz, G., \& Acar, S. (2019). Farklı Bölgelerden Toplanan Arı Polenlerinin Fizikokimyasal Özellikleri ve Şeker Profillerinin Belirlenmesi. Avrupa Bilim ve Teknoloji Dergisi, (15), 627-631.

Çelemli, Ö. G., Barkan, P., Özenirler, Ç., Demiralp, D. Ö., \& Sorkun, K. (2017). Protein Analysis of Anzer Bee Pollen by Bradford Method. Mellifera, 17(1): 21-32.

Davis, P. H. (1965-1985). Flora of Turkey and East Aegean Islands (Vol. 1-9). Edinburg, UK: Edinburg University Press.
Erdogan, Y., \& Dodologlu, A. (2005). Importance of Pollen In Life of Honeybee (Apis mellifera L.) Colonies. Uludag Bee Journal, 5(2):79-84.

Ghosh, S., Jeon, H., \& Jung, C. (2020). Foraging behaviour and preference of pollen sources by honey bee (Apis mellifera) relative to protein contents. Journal of Ecology and Environment, 44(1), 4.

Guler, A. (2017). Bal Arısı (Apis mellifera L.) Yetiştiriciliği, Hastalıkları ve Ürünleri. ISBN: 978-605-84656-3-3. Bereket Akademi Yayınları. 419s.

Gungor, I., Atatoprak, A., Ozer, F., Akdag, N., \& Kandemir, N. I. (2007). Bitkilerin Dünyası. Bitki Tanıtım Detayları ile Fidan Yetiştirme Esasları. Ankara.

Komosinska-Vassev, K., Olczyk, P., Kaźmierczak, J., Mencner, L., \& Olczyk, K. (2015). Bee pollen: chemical composition and therapeutic application. EvidenceBased Complementary and Alternative Medicine: eCAM, 2015, 297425. https://doi.org/10.1155/2015/297425.

Louveaux, J., Maurizio, A., \& Vorwohl, G. (1978). Methods of melissopalynology. Bee world, 59(4), 139-157.

Lunau, K. (2000). The ecology and evolution of visual pollen signals. Plant Systematics and Evolution, 222: 89-111.

Özkök, A., \& Sorkun, K. (2016). Pollen Morphology of Opium Poppy (Papaver somniferum L.) Pollen Collected by Honeybees and Honeybees Tendency to Opium Poppy Flowers. Mellifera, 16(2), 55-60.

Öztürk, A. İ., Yalçın, L. İ., \& Tutkun, E. (2001). Arıcılık. YAYÇEP, 33(1), 101.

Radev, Z. (2018). Variety in protein content of pollen from 50 plants from Bulgaria. Bee World, 95(3), 81-83.

PalDat, (2015). Palynological Database. Retrieved from https://www.paldat.org

Roulston, T. H., Cane, J. H., Buchmann, S. L. (2000). What governs protein content of pollen: pollinator preferences, pollen-pistil interactions, or phylogeny? Ecological Monographs, 70(4), 617-643

Sammataro, D., \& Avitabile, A. (1998). The Beekeeper's Handbook (Third Edition). Cornell Univ. Press.

Sawyer, R. (1988). Honey identification. Cardiff Academic Press.

Sorkun, K. (2008). Türkiye'nin nektarlı bitkileri, polenleri ve balları. Palme Yayıncılık.

Taha, E. K. A., Al-Kahtani, S., \& Taha, R. (2019). Protein content and amino acids composition of bee-pollens from major floral sources in Al-Ahsa, eastern Saudi Arabia. Saudi Journal of Biological Sciences, 26(2), 232237.

Tellería, M. C., Salgado-Laurenti, C. R., Marinozzi, L. A., Apóstolo, N., \& Pérez, B. (2019). Protein content of pollen of asteraceae collected by honey bees. Bee World, 96(4), 104-107.

Tutkun, E. (2011). Arıcılık Tekniği. Ankara, Turkey: Önder Matbaacılık Ltd. Şti. 